IRSH 64 (2019), pp. I-35 doi:10.1017/S0020859019000178

(C) 2019 Internationaal Instituut voor Sociale Geschiedenis

\title{
Indigeneity, Dissent, and Solidarity: Māori and Strikes in the Meat Industry in Aotearoa New Zealand During the Long I970s*
}

\author{
TOB Y B ORAMAN \\ Massey University, Aotearoa New Zealand \\ E-mail: t.boraman@massey.ac.nz
}

ABSTRACT: Studies of indigenous workers' resistance focus largely on rural workers. In contrast, this article examines indigenous workers' dissent in an industrialized and largely urbanized setting - that of Māori meat processing workers in Aotearoa New Zealand. I argue that far from being passive victims of colonization and capitalism, Māori meatworkers played an often vital role in the generally extensive informal and formal labour unrest that occurred in the meat industry during the late i960s to the mid-I980s. However, Māori meatworkers' resistance and solidarity was not universal, but instead varied significantly, both spatially and temporally. The dissent and solidarity that occurred were often a product of the multi-ethnic informal work groups that existed in many slaughterhouses. These workplace-whanan, in which Māori played a pivotal role, functioned similar to extended family networks on the killing floor. Workplace-whānau represented a significant intertwining of indigeneity and class. Nevertheless, as they were often based on masculine bonds, they frequently excluded female workers (including Māori women).

\section{INTRODUCTION, HISTORIOGRAPHY, AND THEORY}

While the global labour history school has enriched and widened the scope of labour history, indigenous workers remain largely neglected within that tradition. ${ }^{\mathrm{I}}$ This is despite Van der Linden noting that many ethnographic

\footnotetext{
* My thanks to the three anonymous reviewers of this article and the editor for their helpful comments, everyone that I interviewed, and finally to the re:work International Research Centre Work and Human Lifecycle in Global History of Humboldt University for a fellowship to research and write, in part, earlier drafts of this article. Any errors in this article are my sole responsibility.

I. See, for example, Jan Lucassen (ed.), Global Labour History: The State of the Art (Bern, 2006); and Marcel van der Linden, "The Promise and Challenges of Global Labor History", International Labor and Working-Class History, 82 (2012), pp. I-2 I. However, Leon Fink (ed.), Workers Across the Americas: The Transnational Turn in Labor History (New York, 20II), contains a section about indigenous labour.
} 
studies can be read as indigenous labour history. ${ }^{2}$ Perhaps this oversight is due to the widespread perception that colonization has corralled indigenous peoples into "communities of abject poverty, underdevelopment, dependence and isolation". ${ }^{3}$ In response to this endangered peoples narrative, scholarship about indigenous people and work has commonly emphasized their resilience and agency. Authors have documented how colonization has not necessarily induced cultural assimilation and the complete marginalization of indigenous peoples; instead, the workplace - among other locations - is perceived as a significant site of indigenous adaption. However, this anthropological literature mostly overlooks class and workplace antagonism. ${ }^{4}$

Most publications about indigenous labour dissent are focused on Latin America. Scholars have highlighted the pivotal role that indigenous peoples have played in labour unrest and wider social struggles throughout Latin America, particularly against neoliberal globalization from the I990s onwards. ${ }^{5}$ Yet, in terms of strikes, most of these studies, with some exceptions, dwell on rural wage labourers' disputes in haciendas and plantations, or the struggles of largely peasant farmers. ${ }^{6}$ A paucity of scholarship specifically examines indigenous workers' resistance in a largely urbanized, "white settler capitalist" or "settler colonialist" context, such as the US, Canada, Australia, and Aotearoa New Zealand. Of that literature, most of it either concentrates on rural workers' disputes, especially in Australia, or it surveys earlier phases of colonization when, in certain regions such as British Columbia, the exploitation of indigenous labour was significant for the expansion of capital and the state. ${ }^{7}$

2. Marcel van der Linden, "Reading Ethnography as Labour History: The Example of the Latmul, East Sepik Province, Papua New Guinea”, Labour History, 89 (2005), p. 209.

3. David Arnold, "Work and Culture in Southeastern Alaska", in Brian Hosmer and Colleen O'Neill (eds), Native Pathways: American Indian Culture and Economic Development in the Twentieth Century (Boulder, CO, 2004), pp. I62-I63. While Arnold is commenting on American Indian communities, his remark seems applicable to indigenous people globally.

4. Colleen O’Neill, "Indigenous Peoples and Labor Systems: Introduction”, in Fink (ed.), Workers Across the Americas, p. I04. See also Alice Littlefield and Martha Knack, Native Americans and Wage Labor (Norman, OK, 1996), and Carol Williams (ed.), Indigenous Women and Work: From Labor to Activism (Urbana, IL, 2012).

5. See for instance Ana Dinerstein, The Politics of Autonomy in Latin America: The Art of Organising Hope (Basingstoke, 2015); and Jeffery Webber, Red October: Left-Indigenous Struggles in Modern Bolivia (Leiden, 201 I).

6. See for example Marc Becker, Indians and Leftists in the Making of Ecuador's Modern Indigenous Movements (Durham, NC, 2008); Philippe Bourgois, "Conjugated Oppression: Class and Ethnicity among Guaymi and Kuna Banana Workers", American Ethnologist, is (1988), pp. 328-348; and Vincent Peloso, Peasants on Plantations: Subaltern Strategies of Labor and Resistance in the Pisco Valley, Peru (Durham, NC, 1999).

7. Taking Canada and Australia as examples, see Minoru Hokari, "From Wattie Creek to Wattie Creek: An Oral Historical Approach to the Gurindji Walk-off”, Aboriginal History, 24 (2000), pp. 98-1 16; Rolf Knight, Indians at Work: An Informal History of Native Labour in British Columbia 1858-1930 (Vancouver, 1996); John Lutz, "After the Fur: The Aboriginal 
Māori have only recently begun to be included in labour history in Aotearoa New Zealand. Yet, the growing literature about this topic possesses a largely institutional focus on Māori leadership and participation within trade union structures, rather than Māori involvement in stoppages and rank-and-file activity, and the interplay between class and indigeneity. ${ }^{8}$ This article argues that Māori meatworkers' resistance sprang not only from their economic and political circumstances - including a severe recession - and from formal union organizations, but also from informal, flaxroots organization (meaning a Māori form of grassroots organization, as flax is commonly perceived to be more of a native species to Aotearoa New Zealand than grass). ${ }^{9}$ Māori meatworkers often made their gruelling, monotonous jobs more sociable, fun, and less alienating by creating strong multiethnic workplace bonds based on whänaungatanga (kinship or camaraderie created by family-like relationships and connections). Melissa Williams, in her magisterial history of Māori urban migration, calls these informal work groups workplace-whānau, a term that denotes "a particular kind of connectedness amongst a group of people who work together" like an extended workplace family. ${ }^{10}$ Such indigenous forms of togetherness are usually neglected in global studies of solidarity. ${ }^{\mathrm{II}}$ Below it is argued that while workplace-whanan were a product of Māori cultural forms, they were also shaped by material conditions, union traditions of solidarity, and workplace conflict.

This article endeavours to begin to fill the research gaps identified above through a study of Māori participation in, and influences on, disputes in the meat processing industry during the "long I970s", which is loosely defined for the purposes of this article as the period from the late ig6os to the mid-I 980 s. That industry makes an ideal case study of indigenous participation in workplace solidarity and resistance (including the broader strike

Labouring Class of British Columbia, I849-1890”, in Bryan Palmer and Joan Sangster (eds), Labouring Canada: Class, Gender, and Race in Canadian Working-Class History (Toronto, 2008), pp. 17-34; and Lyn Riddett, "The Strike that Became a Land Rights Movement: A Southern 'Do-Gooder' Reflects on Wattie Creek 1966-74”, Labour History, 72 (1997), pp. 50-65.

8. The literature on Māori labour history has expanded greatly in recent years, largely through the efforts of Cybèle Locke. See her publications Workers in the Margins: Union Radicals in Post-War New Zealand (Wellington, 20I 2); "Māori Sovereignty, Black Feminism and the New Zealand Trade Union Movement", in Williams (ed.), Indigenous Women and Work, pp. 254267; and "From Human Rights to Māori Sovereignty: Māori Radicalism and Trade Unions, 1967-86", in Rachael Bell et al. (eds), The Treaty on the Ground (Auckland, 2017), pp. 73-90. 9. The term "meatworkers" is preferred in this article to describe those working in slaughterhouses rather than "meatpackers" or "freezing workers" as those terms only describe one part of the labour process.

ıo. Melissa Matutina Williams, Panguru and the City, Kāinga Tabi, Käinga Rua: An Urban Migration History (Wellington, 2015), p. I8 I.

I I. See for example Graham Crow, Social Solidarities (Buckingham, 2002) and Lawrence Wilde, Global Solidarity (Edinburgh, 2013). 
wave of the long 1970s), and experiences of Fordist assembly-line work, during a tumultuous period. The long I 970 s represented, compared to other periods of Aotearoa New Zealand history, the lengthiest and most widely supported period of sustained strike activity nationally. Māori were conspicuous in the largest and longest disputes, the biggest wildcat strikes, workplace occupations, and rank-and-file movements, and the most strike affected industries of the long I 970 . Meat processing itself was the most strike-prone industry nationally, responsible in the long I970s for between fifty and sixty per cent of workers involved in strikes and working days not worked due to all industrial stoppages. ${ }^{\text {I2 }}$

Among other influences from the history from below tradition, this article draws upon the "autonomist Marxist" school. Mario Tronti famously declared that orthodox Marxism "puts capitalist development first, and workers second". Instead, Tronti and other autonomists reversed this polarity: "the beginning is the class struggle of the working class". ${ }^{13}$ Their "workers' inquiries" aimed to study workers' multifarious forms of shop floor resistance (both formal and informal), and their perceived self-organized autonomy (from capital, work, and unions). Importantly, even if autonomists' historical periodization could be schematic, they developed an open-ended, historically contingent method - "class composition" analysis - to study the temporal transformations of class relations. Briefly, this framework suggests that as capital develops innovative productive processes, workers eventually respond by developing new forms of solidarity and resistance, and thus a new "class composition" is forged. In turn, capital then endeavours to co-opt and break up ("decompose") these nodes of dissent and unity, and intensify divisions among workers, in order to increase capital accumulation and harness struggle to enable new innovations in production and consumption. Hence autonomists scrutinized carefully not only points of unity between workers, but also internal stratifications. After initially focusing their inquiries on male and white dominated assembly-line workers, they broadened their gaze to study migrant, women, unwaged, and indigenous workers. ${ }^{14}$ Yet, much autonomist analysis of indigenous people's resistance focuses on Latin American social movements during the neo-liberal era rather than the workplace. ${ }^{\text {Is }}$

I2. All figures were calculated from various annual issues of the New Zealand Yearbook and the Department of Labour's Industrial Stoppages Report. Overall figures for 1975 were not published and specific figures for workers involved in the meat industry were not published for 1968-i 970.

I 3. Mario Tronti, “Lenin in England”, Classe Operaia, I (1964), available at: https://www.marxists.org/reference/subject/philosophy/works/it/tronti.htm; last accessed 2 May 2018.

I4. See Steve Wright, Storming Heaven: Class Composition and Struggle in Italian Autonomist Marxism (London, 2002), pp. 176-196.

I 5. See for instance Harry Cleaver, "The Zapatista Effect: The Internet and the Rise of an Alternative Political Fabric", Journal of International Affairs, 51 (1998), pp. 62I-640 and Dinerstein, The Politics of Autonomy in Latin America. 
Given this broad history from below framework, where possible the words of Māori themselves are given primacy, including interviews of Māori in various socialist and other publications, reports, theses, and documentaries. This research has been supplemented by interviews with former meatworkers undertaken by the author. Socialist Action, the paper of the Trotskyist Socialist Action League (SAL), is used as a valuable source because it was the only publication of the period that interviewed a wide variety of Māori meatworkers. While the SAL was quite marginal in influence, it was unique in the local context as it focused on rank-and-file organizing in the meat industry and was also sympathetic to Māori issues. ${ }^{16}$ This article also draws upon a wide variety of complementary government, union, employer, and newspaper sources. Yet, as these latter sources possess only fleeting content specifically about rank-and-file Māori meatworkers, they are used less extensively than the aforementioned sources.

Autonomist Marxism is not adopted uncritically, however. One of its major flaws is that it can uncritically inflate the extent of workers' agency, resistance, and solidarity, and correspondingly neglect how the wider intertwining structures of capitalism, sexism, racism, and colonialism mould labour. ${ }^{17}$ As such, this article argues that while Māori meatworkers' militancy and solidarity were relatively widespread during a major strike wave, they were ambiguous (as they were combined with cooperation with employers and workers' pride in work) and uneven, both historically and geographically. Furthermore, Māori meatworkers' resistance and solidarity were firmly situated inside wider and powerful structures of subjugation that, to some extent, shaped and constrained their agency. Indeed, structural transformations in the meat industry eventually had a debilitating effect on meatworkers' solidarity and resistance in the I980s.

This article first presents contextual material, briefly outlining Māori land loss, labour migration, and the nature of work and causes of disputes in the meat industry. Two broad historical phases of meatworkers' strike activity are then analysed. The first occurred from the late i960s to the mid-i970s when dissent, often led by Māori meatworkers, emerged after a long period of relative quietude. As this activity was frequently based on informal shop floor bonds, the nature of workplace-whanan will then be explored in terms of the unity and stratifications upon which they were founded. Finally, the second period of strike activity from the mid-r970s to the mid-r980s will be explored, a phase when strike activity peaked during a recessionary period that marked the beginnings of comprehensive industry restructuring.

16. Some regarded Socialist Action as a meatworkers' paper, as it contained much coverage of the meat industry. As far as is known, those quoted from Socialist Action in this article were not SAL members.

17. See for example Marcel van der Linden, "Labour History as the History of the Multitudes", Labour/Le Travail, 52 (2003), pp. 235-243 (a review of Peter Linebaugh and Marcus Rediker's autonomist history The Many-Headed Hydra (Boston, MA, 2000). 
Except in passing, scrutinizing the complex links - and tensions - that developed between workplace dissent and the renaissance in Māori protest during the long I970s is beyond the purview of this article. Further, this article does not explore how, by the early i 980 , many Māori attempted to re-shape union structures and aims to reflect Māori tikanga (customs) and causes. Instead, this article largely focuses on industrial conflict and self-organization.

\section{CONTEXT, WORKING CONDITIONS, AND CAUSES OF DISSENT}

Glen Coulthard has argued that the ongoing "structured dispossession" of indigenous peoples' lands is central for the expansion of capital and the state in Canada, rather than the exploitation of indigenous labour. He contends that following waves of white settlement between I860 and I9I4, "native labor became increasingly (although by no means entirely) superfluous" to "development". ${ }^{8}$

While the enduring expropriation of Māori land is likewise paramount for capital accumulation in Aotearoa New Zealand, capital's exploitation of Māori labour has often been significant for "development" beyond the early phase of British colonization in the nineteenth century. This was particularly the case during the Keynesian era (which existed locally between about 1935 and 1984) when capital and the state increasingly used Māori as a largely cheap labour source for manual labour during that period of industrial expansion. ${ }^{19}$

To examine briefly the extensive appropriation of Māori land, while the Treaty of Waitangi (I 840) guaranteed Māori the "exclusive and undisturbed" possession of their land and other resources, by the I970s almost ninety-five per cent of that land had been alienated. ${ }^{20}$ Ben Matthews - a prominent Māori meatworker and the secretary of the Wellington branch of $\mathrm{Te}$ Matakite, a prominent Māori land rights organization that was formed around the Māori land march or bìkoi of 1975 - argued that institutionalized racism intertwined with capitalism meant that Māori found themselves marginalized culturally, politically, and economically. Matthews implied that a major reason for this marginalization was the "systematic" and "ruthless"

I 8. Glen Coulthard, Red Skins, White Masks: Rejecting the Colonial Politics of Recognition (Minneapolis, MN, 2014), pp. I2-I3.

19. In I98 I, for example, nearly ninety per cent of the Māori male workforce worked in manual occupations, and seventy-one per cent of Māori females. David Pearson, A Dream Deferred: The Origins of Ethnic Conflict in New Zealand (Wellington, 1990), p. I 3 I.

20. Calculated from Evan Poata-Smith, "The Political Economy of Māori Protest Politics" (Ph.D., University of Otago, 200I), pp. I90-I9I. 
programme of land seizures and alienations after colonization, which broke up the "traditional communality of the Māori people" by individualizing their communal ownership of land. ${ }^{21}$

Although the causes of urbanization are multifarious, these often brutal land enclosures were a significant underlying, long-term factor in causing the eventual mass Māori migration to urban areas from about the I940s to the I960s, although this migration was neither historically linear, nor geographically uniform. ${ }^{22}$ By the 1960s, most Māori had become urbanized and, in 1976, seventy-six percent of Māori were dwelling in urban areas. ${ }^{23}$ Perhaps one important reason why Māori labour became increasingly significant during this era was simply because Māori represented an appreciably larger proportion of the population than indigenous peoples in other white settler capitalist colonies. For example, in I98I, Māori made up about twelve per cent of Aotearoa New Zealand's population and less than ten per cent of the total workforce. Yet, in Canada, First Nations peoples totalled two per cent of the population in $198 \mathrm{I}$, and in the US, 0.6 per cent in $1980 .{ }^{24}$

Whereas most Māori workers occupied the bottom fractions of the working class, a large minority of Māori workers - particularly males - worked in key export industries in Aotearoa New Zealand's agro-export economy, an economy largely reliant on exporting pastoral products (meat, wool, and dairy produce). ${ }^{25}$ During the I970s, Aotearoa New Zealand was the largest sheep meat exporter globally, and meat exports accounted for about forty per cent of export earnings, making it the most important export nationally. ${ }^{26}$ Meatworkers utilized these strategic positions during the strike wave.

21. Ben Matthews, "He Toka Tu Moana", Socialist Action, 25 Feb. 1977, p. I6.

22. See Robert Miles and Paul Spoonley, "The Political Economy of Labour Migration: An Alternative to the Sociology of 'Race' and 'Ethnic Relations' in New Zealand”, Journal of Sociology, 2 I (1985), pp. 3-26; Robert Miles, "Summoned by Capital: The Political Economy of Labour Migration", in Paul Spoonley et al. (eds), Taniwi: Racism and Ethnicity in New Zealand (Palmerston North, 1984), pp. 223-243; and Pearson, A Dream Deferred, pp. Iо8, I I I-I I 4 .

23. Locke, Workers in the Margins, p. 36; and Rawiri Taonui, "Māori Urban Protest Movements," in Danny Keenan (ed.), Huia Histories of Māori: Ngā Tābubu Kōrero (Wellington, 2012), p. 233.

24. Magali Barbieri and Nadine Ouellette, "The Demography of Canada and the United States from the I980s to the 2000s", Population, 67 (2012), pp. 177-280 and Warren Kalbach, "Population", available at: http://www.thecanadianencyclopedia.ca/en/article/population/; last accessed 20 May 2017. Aotearoa New Zealand statistics calculated from Katherine Gibson, "Political Economy and International Labour Migration: The Case of Polynesians in New Zealand", New Zealand Geographer, 39 (1983), p. 3 I; and New Zealand Census of Population and Dwellings (Wellington, I98 I).

25. Tama Poata, Poata: Seeing Beyond the Horizon (Wellington, 2012), p. 100.

26. N. Blyth, A Review of the World Sheepmeat Market (Lincoln, Aotearoa New Zealand, 1981); and Don Turkington, Industrial Conflict: A Study of Three New Zealand Industries (Wellington, 1976), p. 3 I. 
By the I960s, the food processing industry had become the primary employer of Māori men. Although no official records of the number of Māori in the meat processing industry were kept, meatworkers' union officials estimated about forty to fifty per cent of the 30,000-strong meat processing workforce of the I970s were Māori, and in many plants (Figure I) - particularly those in the North Island - majority Māori. ${ }^{27}$ The workforce was overwhelmingly male-dominated; only 4.6 per cent of the workforce was female in 1972-1973, of whom many were Māori women. ${ }^{28}$

Meatworkers were almost archetypal Fordist assembly-line workers who were at the forefront of industrial struggle, just as autoworkers were in other core capitalist countries during the I 960 s and I 970 s. ${ }^{29}$ However, meatworkers faced more obnoxious working conditions on the "dis-assembly line" as they progressively dismembered thousands of sheep and cattle every day. Although the causes of meatworkers' unrest in the I 970 s were intricate and multifaceted, the most pivotal factors were probably dissatisfaction with everyday working conditions combined with the unsettling effects of a deep recession after a long period of relative prosperity. ${ }^{3 \circ}$

A strong underlying discontentment with the monotonous, dirty, smelly, brutal, and "blood and guts" nature of meat processing work played a fundamental role in generating conflict throughout the 1970s. ${ }^{3 \mathrm{I}}$ Working conditions were highly regimented. After animals were killed, they were hung on a moving "chain" (Figure 2). Different specialized departments of workers then progressively disassembled those carcasses as they travelled past. Each worker performed the same cut or task on each carcass until almost every part of the animals had been processed and commodified. Matthews captured well the unrelenting pressure of butchers "slaving away", repeatedly executing the same task every eight seconds:

27. Ben Matthews estimated fifty per cent (Socialist Action, 25 Feb. 1977) and Roger Middlemass estimated about forty per cent (Socialist Action, 23 October 1981).

28. Turkington, Industrial Conflict, p. $3 \mathrm{I}$.

29. Beverly Silver, Forces of Labor: Workers' Movements and Globalization Since 1870 (Cambridge, 2003), pp. 43-54.

30. Although many other factors also contributed, such as the strict hygiene requirements of the European Economic Community and the US, which forced companies to upgrade plants and modify the work process, thus resulting in conflict. For some of the many publications about the complex causes of meatworkers' dissent see, for example, A. J. Geare, "The Problem of Industrial Unrest: Theories into the Causes of Local Strikes in a New Zealand Meat Freezing Works", Journal of Industrial Relations, I4 (1972), pp. I3-22; Kerr Inkson, "The Man on the Dis-assembly Line: New Zealand Freezing Workers", Australian and New Zealand Journal of Sociology, I 3 (1977), pp. 2-I I; and Turkington, Industrial Conflict.

3 I. Department of Labour, Work Stoppages in the Meat Freezing Industry Part II (Wellington, I973); Geare, "The Problem of Industrial Unrest"; Kerr Inkson and Peter Cammock, "Labour Process Theory and the Chain System in the New Zealand Meatworks", New Zealand Journal of Industrial Relations, 9 (1984), pp. I49-160; and Turkington, Industrial Conflict. 


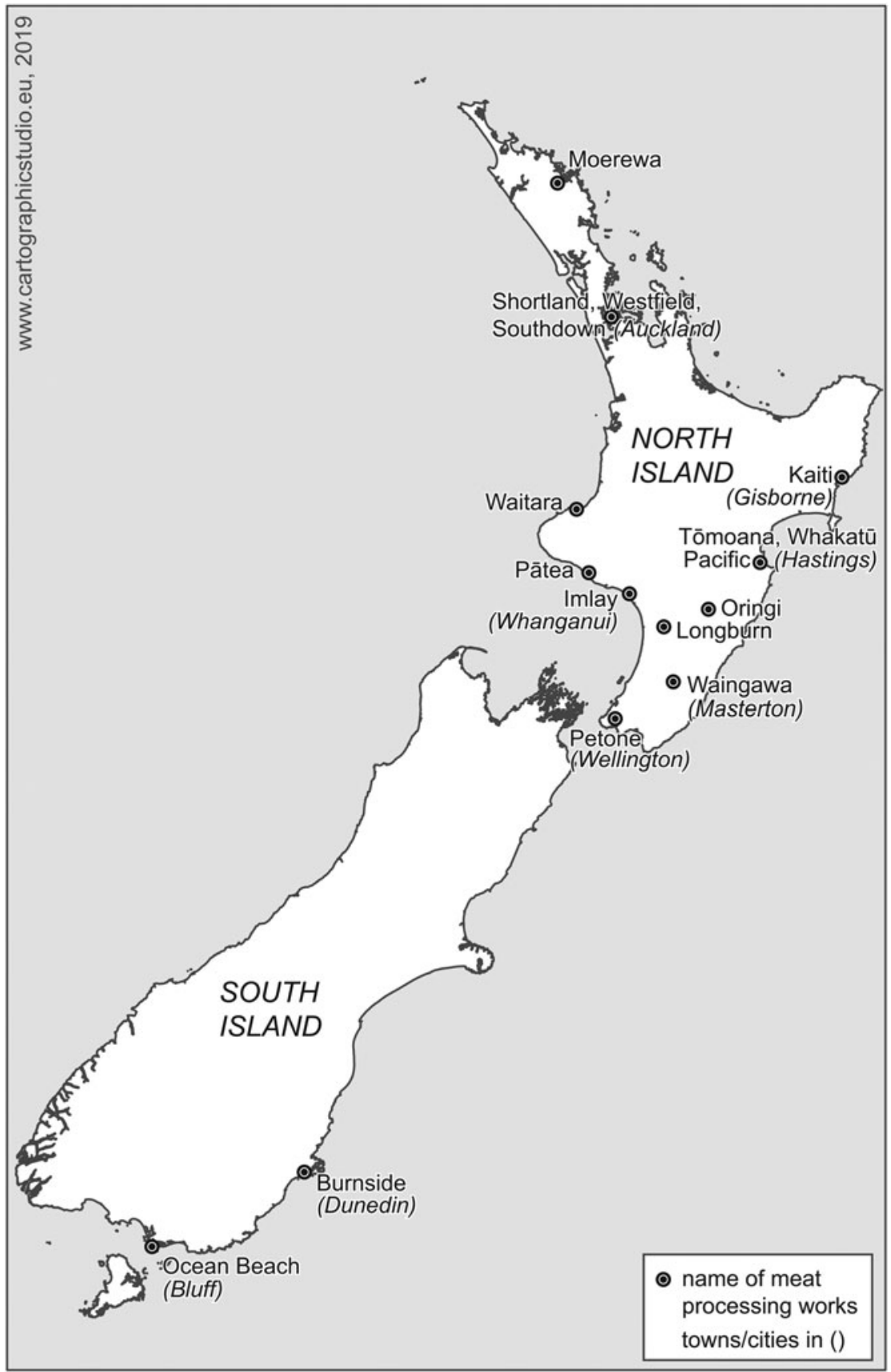

Figure I. Aotearoa New Zealand meat processing plants mentioned in the article. 


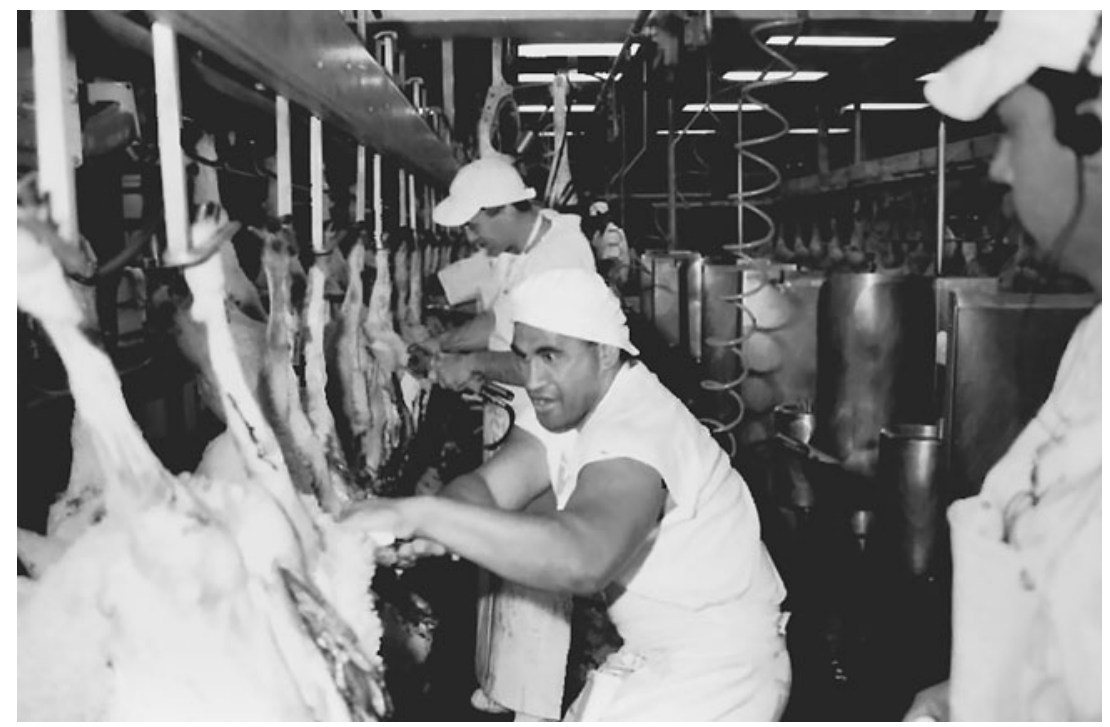

Figure 2. Mac Te Houkamau (centre) and Billy Greening working on the dis-assembly line or 'chain' at Tōmoana, n.d., c.I980s, available at: https://numawaruwire.wordpress.com/tag/ tomoana/\#jp-carousel-248; last accessed i 8 January 2019.

One must envisage the scene of men working shoulder-to-shoulder, each handling a knife at speed, blood, steam, hot water, excrement, noise, urine, foremen [...] and the chain constantly moving at eight links per minute past a given point. ${ }^{32}$

Many, such as Shirley Tareha, found the work utterly mundane. She said, "labouring, to me, was that boring I used to just about go to sleep everyday". ${ }^{33}$ It could also be exhausting and dangerous, as cuts and other accidents occurred frequently. The shed (the commonly used term for a slaughterhouse) floor could be slippery with water and blood, and in the freezing chambers it was often icy. Many workers acquired diseases from animals. Temperatures could vary between extremes of fifty-five degrees Celsius during summer and minus thirty in the freezers. Workers also lacked job security, as the work was seasonal; sometimes the killing season only lasted three or four months.

The end of the long boom, and the grave recession that followed, were also major triggers for meatworkers' dissent. As Van der Velden notes, major strike waves often occur during a shift from economic upturn to downturn. ${ }^{34}$

32. Ben Matthews, "A Day in the Life of a Meatworker Unionist”, Socialist Action, 6 May I977, p. I 2.

33. Quoted in Socialist Action, I 8 May 1984.

34. Sjaak van der Velden, "Introduction", in Sjaak van der Velden et al. (eds), Strikes Around the World, 1968-2005: Case Studies of Is Countries (Amsterdam, 2007), p. I 3. 
As in many other countries, such a strike wave in Aotearoa New Zealand commenced in 1968. After a minor recession in the late 1960s, stoppages increased in size and frequency as the Keynesian class compromise that previously existed between capital, the state, and labour began to rupture. Yet, unlike many countries, the strike wave peaked between the mid-r97os and the mid-I980s when the recession deepened, despite fluctuations in strike activity during those years. ${ }^{35}$

As high inflation and rising living costs often ate into wage increases, meatworkers commonly sought greater pay, especially through piecework payments. Such "bonuses" were often gained through localized shop floor strikes. Before the I960s, companies commonly paid the most strategic workers near the front of the dis-assembly line - the butchers - piecework rates. Other meatworkers, paid at an hourly rate, increasingly took action in the I960s and I970s to gain incentive bonuses. Consequently, workers received at least 250 different payment rates across the industry. ${ }^{36} \mathrm{~A}$ further consequence of performance payments was to speed up production - what autonomists call the Keynesian "productivity deal", meaning "the attempt to use working class struggle for higher income to promote [capital] accumulation by linking increased wages to increased productivity". ${ }^{37}$ The accelerated pace of work caused increasing numbers of injuries and greater dissatisfaction with the nature of the work - and hence more dissent.

\section{THE LATE I 960 S TO THE MID-I 970S: EMERGENCE}

Some slaughterhouses, such as Longburn, Ocean Beach, and Petone, recruited many Māori during the labour shortage and relative industrial quietude of the I950s and I960s in the hope of importing a hard-working, compliant workforce. ${ }^{38}$ Ewin Kirk, the manager of Ocean Beach during that period, starkly alleged that Māori were unable to save money from

35. Toby Boraman, "Merging Politics with Economics: Non-industrial and Political Work Stoppage Statistics in New Zealand during the Long 1970s", New Zealand Journal of Employment Relations, 4I (2016), pp. 69-73.

36. Mick Calder and Janet Tyson, Meat Acts: The New Zealand Meat Industry 1972-1997 (Wellington, 1999), p. 73; and Roger Middlemass, interview by author, digital recording, Palmerston North, 2 October 2013, 25'17" to 26'32".

37. Harry Cleaver, "Food, Famine and the International Crisis", Zerowork, 2 (1977), p. 24. See also John Holloway, "The Abyss Opens: The Rise and Fall of Keynesianism”, in Werner Bonefeld and John Holloway (eds), Global Capital, National State and the Politics of Money (New York, I995), pp. 7-34.

38. Keith Locke, "A History of Struggle at Gear Meat Works", Socialist Action, 2 April I982, p. 5; Longburn sub-branch New Zealand Meat Workers' Union, "Submissions to the Inquiry into Industrial Relations at Longburn" (1974), Longburn History I890-1996 folder, New Zealand Meat Workers' Union Aotearoa branch files, p. Is; and Michael Turner, One Muff too Tough: Ocean Beach (Invercargill, 1984), pp. I7-I8. Polynesians, including Māori and 
their jobs, and thus hoped they could not afford to strike. ${ }^{39}$ As the long boom abated, meatworks such as Longburn and Ocean Beach, previously renowned for their sparse strike records and "industrial harmony", became hotspots of industrial unrest during the late i960s and early i 970 s. This discontent was often driven from below and, in many plants, was seemingly organized by a new layer of young Māori rank-and-file leaders who became union delegates. ${ }^{40}$ However, some Māori union officials, such as Tony Taurima, the secretary of the Ocean Beach sub-branch of the New Zealand Meat Workers' Union (MWU), also seemed pivotal in causing increased workplace militancy. For Taurima, promoting industrial action was not just about securing better pay, but was also a riposte to harsh management practices, as in the late I960s "people were dismissed, wholesale and frequently. In those days it was a master-servant relationship"..$^{\mathrm{I}}$

A similar reaction to paternalistic, authoritarian management practices developed at the Longburn slaughterhouse that employed many Māori from neighbouring areas such as Foxton. ${ }^{42}$ There, according to Sonny Rata, management ruled with an "iron hand". Yet, from the late I960s onwards:

We learnt a new war that many of us had trouble to understand. After all, we just wanted to work and play and drink and love and do the same again, maybe to eternity. The new war was getting up bleary eyes [sic] to paint a sign on the road or sit in the C. W. S. [Cooperative Wholesale Society] head office in Wellington together with our spouses. ${ }^{43}$

This illustrated a broader tendency whereby workers developed innovative tactics in the "new war" with capital, such as occupying company headquarters.

Dissent during this phase was largely expressed through a plant-based or localized militancy aimed at securing better wages and working conditions. ${ }^{44}$ Under conditions of full employment and a labour shortage, stoppages were

Cook Islanders, made up about forty per cent of the seasonal Ocean Beach workforce. Helen Paske, "The Tide Turns at Ocean Beach", The Listener, 2 August 1980, p. I8.

39. Cited in Turner, One Muff too Tough, p. I8.

40. Michael Law to Charles Sedgwick, undated letter, Alexander Turnbull Library, Wellington (hereafter, ATL), "Maori and Trade Unions, I940-83" folder, Bert Roth papers 94-106-72/19; Eugen Lepou, interview by author, digital recording, Auckland, I 9 December 2013, 54 '05" to 54'30"; Helen Mulrennan, interview by author, digital recording, Auckland, i 8 December 2013 , 5I'26" to 5I'35"; and James Robb, interview with author, digital recording, Auckland, I0 October 2013 , I:33'20" to I: 34 'I 6 ".

4I. Quoted in Paske, "The Tide Turns", p. I 8.

42. Ken Findlay, interview by author, digital recording, Wellington, 2 I January 20 I4, 4:06'05" to 4:06' 'о"; and Middlemass, interview, 55'50" to 56'05".

43. Sonny Rata, "In Summary", in Longburn Freezing Works I890-1986: Longburn Freezing Works Reunion (n.p., 2000), p. 35. The CWS were a British company.

44. Jim Pearson, "Introduction", in Into the I980s: The Struggle for a Fighting National Union of Meat Workers (Auckland, 1984), p. iii. 
typically short, sharp, and successful. They were nicknamed "homers" (meaning to go home) and took two major forms: local agreement strikes and wildcat strikes, although both often merged into each other. The former were union-based plant or work department strikes characteristically centred on securing local agreements, especially over piecework incentives. Significant pay rises were gained during this phase through these "second tier" agreements, which were made over and above the national collective bargaining agreement. ${ }^{45}$

The second major form of stoppages were wildcats, which became commonplace in many plants. At Longburn, for instance, a government inquiry claimed that, between 1969 and I974, a total of 362 unauthorized stoppages occurred, resulting in 250,000 hours not worked. ${ }^{46}$ Even if these figures were grossly inflated, they still represented a relatively vast sum; for example, in I974 alone, the official national total for all industries of hours not worked due to strikes was 240,000 hours. ${ }^{47}$ Disputes at Longburn during this period centred on issues of temperature extremes, work speeds, pay (including piecework rates), and the selection and role of supervisors, among a multitude of other conflicts. ${ }^{48}$

Given the repugnant, repetitive nature of meat processing, wildcats could result from "any minor incident". ${ }^{49}$ For example, the Māori President of the highly strike-prone Westfield union branch of the Auckland and Tōmoana Freezing Workers' Union (FWU), Bill Hillman, claimed that:

in the height of the season you had four chains going, you had fifty-eight mutton butchers on it and about forty labourers. And the noise. And the heat. And the boys would get frustrated with it and at 2 o'clock, bang, that's it for the day. They wanted a release. ${ }^{50}$

Similarly, Rata noted "when days got hot and weary, we hoped something would happen to give us a break" such as when the "gun man" in the "killing box" at the beginning of the dis-assembly line purposively released a live

45. Turkington, Industrial Conflict, p. 25 .

46. Committee of Inquiry, "Findings of Committee of Inquiry, Industrial Relations at Longburn Freezing Works 30 July 1974”, p. I, West Coast Trade Union history folder, New Zealand Meat Workers' Union Aotearoa branch files. However, many stoppages may have been official union strikes that management claimed were "unauthorized".

47. See Boraman, "Merging Politics with Economics", p. 69. Unauthorized stoppages were excluded from official statistics.

48. Rob Campbell, Industrial Conflict at Longburn (Auckland, 1974) and Longburn subbranch, "Submissions to the Inquiry".

49. Geare, "The Problem of Industrial Unrest", p. i 8. See also J. Howells and R. Alexander, "A Strike in the Meat Freezing Industry: Background to Industrial Discontent in New Zealand", Industrial and Labor Relations Review, 28 (1968), pp. 418-426; Longburn sub-branch, "Submissions to the Inquiry"; and Ross Webb, "Your Livelihood is on the Line': Freezing Workers in Aotearoa/New Zealand 1973-1994" (MA thesis, University of Auckland, 201 5). 50. Quoted in Webb, "Your Livelihood is on the Line", p. 99. 
steer to halt production. Two-hundred workers gave chase, half-heartedly, in order to gain as much time off work as they could. ${ }^{51}$

The major meatworkers' unions - the larger MWU and the smaller $\mathrm{FWU}^{52}$ - often officially endorsed wildcat stoppages. They did this because they were militant, struggle-based unions (while not being avowedly radical or socialist) that possessed strong traditions of adhering to "one out, all out" - if one worker struck, all would follow. Crucially, many local branches of meatworkers' unions, including the Longburn sub-branch of the MWU, were considered "super democracies within which the workers, rather than officials, have the power and exercise control". ${ }^{33}$ However, much of this resistance was also enabled by strong informal shop floor bonds and patterns of informal mutual support between many workers, bonds that were often influenced by Māori meatworkers, as will be discussed in the section on workplace-whānan below.

Dissent also took the form of considerable informal resistance. Such everyday resistance typically included time appropriation (including chronic absenteeism and "spelling", whereby workers took spells or breaks from work while others carried out their tasks for them), theft, sabotage, and "over-utilisation of accident compensation, neglect of quality, indiscipline, passive resistance to supervisors and tardiness at critical times" ${ }^{54}$ While quotidian resistance was sometimes individualistic and easily accommodated by management, it could also hamper production and profit levels. Covert dissent was intermixed with, and fed into, substantial overt resistance, and relatively strong traditions of informal workers' control over the work process overlapped with union control. ${ }^{55}$

Māori were not authentically rebellious workers, however. Crouch and Pizzorno have suggested that migrant workers, including internal ruralurban migrants, were at the vanguard of industrial conflict during the I970s in Western Europe. ${ }^{56}$ Yet, as Pizzolato observes about migrants from southern Italy in the late I960s, the predominant image of rebellious southerners in Northern Italian factories has obscured a "multi-faceted working class" wherein "southerners belonged to both sides of the

5. Rata, Longburn Freezing Works I890-1986, pp. 35-36.

52. The MWU was formed after various provincial unions amalgamated in 197I. The Tōmoana plant union joined the FWU in 1978. Pearson, "Introduction", p. ii.

53. Turkington, Industrial Conflict, p. I 27. Although even at Longburn the extent of bottom-up control was limited. See Campbell, Industrial Conflict at Longburn, p. I 3 and Pearson (ed.), Into the 1980 s, p. 29.

54. Inkson and Cammock, "Labour Process Theory", p. I55.

55. Toby Boraman, "Wildcat Homers, Gamifying Work, and Workplace-whānau in the Meat Industry: Re-examining the Subversiveness of Informal Workers' Resistance", Journal of Labor and Society, 20 (2017), pp. 467-485.

56. Colin Crouch and Alessandro Pizzorno, The Resurgence of Class Conflict in Western Europe Since 1968, vol. I (New York, 1978), p. x. 
barricades: the strikers and scabs; the rebels and the policemen". ${ }^{57}$ As with Italian southerners, Māori meatworkers were far from homogenous; many conservative and religious Māori, for example, were either reluctant to strike, or opposed to striking. While some meatworkers, including Māori, were "super militants", others thought the company was always right, and yet others were apathetic. ${ }^{58}$ Importantly, Joe Tepania, who worked at Ocean Beach, said many families were content because "they weren't struggling" as they received "good money" from meat processing in comparison with other industries like transport. ${ }^{59}$ Some older Māori meatworkers with mortgages to pay or families to support seemed more reluctant to strike than younger Māori. Further, meatworkers' dissent was usually intermingled (necessarily) with daily cooperation with management and was interfused with a strong identification with work. Many Māori meatworkers took considerable pride in their jobs. ${ }^{60}$ For example, Jean Te Huia remembers "generations of families worked there [Tōmoana meatworks] and were proud of their jobs and really put their heart and souls into it". ${ }^{6 \mathrm{I}}$

Women were largely excluded from most occupations in the meat processing industry, let alone from participating (or not) in strikes. Some male meatworkers justified this occupational segregation on the grounds that women would allegedly be too obedient, and hence disinclined to strike. For instance, Frank Young, the offal delegate and "Maori activist" at Auckland's Westfield slaughterhouse, said:

At first, I wasn't happy about women getting onto the offal floor [in 1973] because I used to always have this fantasy that the freezing works [meatworks] was a man's world [...] I thought women coming into the department would undermine and spoil things for the union. I never believed women could be good unionists [...] We were worried that if the boss told the women to do something, they would just do what he said without recognising the union. ${ }^{62}$

Yet, over time Young altered his views. Women meatworkers were "good unionists. They're darn good battlers too". He stated sexist attitudes gradually dissipated, culminating in a 1975 strike that successfully reinstated five female workers. ${ }^{63}$ Women meatworkers' struggles to gain employment

57. Nico Pizzolato, “'I Terroni in Città': Revisiting Southern Migrants' Militancy in Turin’s Hot Autumn”, Contemporary European History, 2 I (2012), pp. 627-628.

58. New Zealand Meat Worker, June 1972, p. I9.

59. Joe Tepania, interview by author, digital recording, Porirua, I 2 December 20I3, 24'24" to 24 ' 42 '”.

60. Vera Keefe-Ormsby, Tihei Mauri Ora: The Human Stories of Whakatu (Wellington, 2010), pp. 30-32; M. Nicholls and D. Piesse, The Consequences of Closure: A Study of the Social and Economic Impact of the Southdown Freezing Works Closure (Auckland, 1982), p. I54; and Webb, "'Your Livelihood is on the Line", pp. 59, 94-95.

61. Quoted in Webb, "Your Livelihood is on the Line”, p. 59.

62. Quoted in Socialist Action, 23 April 1980.

63. Quoted in ibid. 
will be discussed more fully below, as they mostly occurred during the later phase.

While a rough correlation between slaughterhouses with disproportionately Māori workforces and high levels of labour unrest existed, the extent and frequency of strikes fluctuated between individual departments, plants, companies, and regions. ${ }^{64}$ For instance, several plants that possessed a disproportionately Māori workforce during the late i 960 s and early i 970 - such as Kaiti, Tōmoana, Pātea, Petone, and Imlay - were among the least strikeprone sheds in the country. Nevertheless, the majority of slaughterhouses with large Māori workforces were among the plants with the highest levels of industrial unrest during this period, such as Moerewa, Southdown, Westfield, Shortland, Waitara, Whakatū, Waingawa, and Ocean Beach. ${ }^{65}$

The nature of management practices and attitudes, and union traditions, were important variables in explaining these geographical variations in strikes. ${ }^{66}$ As plant-based union branches possessed much autonomy from their national organizations, at different times various local branch officials - militant and non-militant, Māori and non-Māori, alike - attempted to discourage or prevent strikes, especially wildcats. ${ }^{67}$ Several union branches with a high proportion of Māori developed a strategy of cooperation with management, and only resorted to strike action as a last resort. For instance, Rangi Paenga - the President of the Kaiti sub-branch of the MWU, and later the national President of the MWU from 1976 to 1986 - said:

Strikes were something I was really opposed to. It did no good for our people, the workers. They lost money. They didn't get the dole. To eliminate strikes, I always tried to reach a compromise with the employer. At times strikes were unavoidable. $^{68}$

Consequently, Kaiti - where about two thirds of the workforce were Māori traditionally experienced few stoppages. ${ }^{69}$

64. Turkington, Industrial Conflict, pp. $4 \mathrm{I}-58$.

65. In terms of working days not worked. Department of Labour, Work Stoppages, table ro, unpaginated.

66. Kerr Inkson, "Management Practice and Industrial Conflict: The Case of the New Zealand Meat Freezing Industry", New Zealand Journal of Business, I (1979), pp. 83-104; and Turkington, Industrial Conflict.

67. Boraman, "Wildcat Homers", p. 475.

68. Quoted in Sheridan Gundry, Making a Killing: A History of the Gisborne-East Coast Freezing Works Industry (Gisborne, 2004), p. I4I. Such views were not representative of the MWU as a whole.

69. Ibid., pp. I 4 I-I 42. Similar strategies developed at other plants, such as the Pacific meatworks under the presidency of Sue Leitch, the first female president of a sub-branch of the MWU, and a Māori, between 1974 and 1976. See Sue Leitch, "My Six Years in the Meat Freezing Industry", New Zealand Meat Worker, June 1976, p. 19; and New Zealand Herald, i I June 1974, ATL, Roth papers, 94-106-39/07. 


\section{WORKPLACE-WHANAU: UNITY AND DIVISIONS}

The generally relatively high pattern of informal and formal labour unrest was sustained by generally strong informal and formal bonds that developed over time under conditions of full employment. Workplace-whānau were prominent in many, but not all, slaughterhouses with significant Māori workforces. ${ }^{70}$ Williams contends that workplace-whanan were established in workplaces where Māori had "critical mass" to "effect cultural change". ${ }^{\mathrm{I}}$ Whànau, normally defined to mean an extended family, are considered to be one of the most fundamental traditional units of Māori society. However, whānau can also mean expressing solidarity on specific occasions with people who share a common purpose. ${ }^{72}$ A workplace-whänau conveys both these meanings: comradeship and treating everyone as a member of an extended family (with the strong reciprocal obligations this generally entails in Māori society). By uniting with workers from other ethnicities, their aim was to transform "often physically demanding, monotonous and impersonal workplaces into bearable, sometimes fun and culturally familiar spaces of community engagement". ${ }^{73}$ These informal bonds overlapped with, and were reinforced by, strong union traditions of solidarity. Both forms of camaraderie were vital for sustaining solidarity and for underpinning informal and formal resistance.

A striking feature of meatworkers was their "impressive solidarity" ${ }^{74}$ For example, Henare O'Keefe remarked about the Tōmoana slaughterhouse where he worked:

Best thing about it was the people, of course. I loved the culture there. I loved the camaraderie, the whakawhanaungatanga, the closeness, the intimacy of it all [...] The camaraderie was the biggest thing. We worked together, we slept together, we socialised together - and there was 2,000 of us [...] It was a real family: an absolute, total family. ${ }^{75}$

70. Keefe-Ormsby, Tihei Mauri Ora; The Black Singlet Legacy, written and directed by Tainui Stephens (Auckland, I99 I [television documentary]); Webb, "Your Livelihood is on the Line"; and Williams, Panguru and the City. Workplace-whanau and Māori have the same form in the singular and plural.

71. Melissa Williams, "Factorying Workplaces into Māori History”, Te Poubere Kōrero: Mãori History, Māori People, 6 (2012), p. I 3.

72. Joan Metge, New Growth from Old: The Whanan in the Modern World (Wellington, 1995), pp. 53-55.

73. Williams, Panguru and the City, p. I90.

74. Inkson and Cammock, "Labour Process Theory", p. i 55 . See also Kerr Inkson, "The Man on the Dis-assembly Line"; Turkington, Industrial Conflict; and Webb, "Your Livelihood is on the Line"”.

75. Quoted in Webb, “Your Livelihood is on the Line”, p. 56. Estimates of the proportion of Māori at Tōmoana range from half to two thirds. Ibid., p. $7 \mathrm{I}$ and Robb, interview, I:40'43”". 
Whakawhanaungatanga may be translated as the practice of relating well to others. Similarly, another Māori meatworker recalled:

the comradeship was phenomenal. We've had Black Power, Mongrel Mob, Highway 6I [gang] members, you name it they all worked at Whakatu [meatworks] [...] They come in the gate [...] with their [gang] patches on, but once they got into their working area, they became one big family. ${ }^{76}$

At Pātea, where seventy per cent of the workforce were Māori, Syd Kershaw also remembered the "everyone together" camaraderie, as working there was also like being amongst "one big family". ${ }^{77}$ Widespread intergenerational employment among Māori in the industry amplified these connections. At Auckland's Southdown plant, for example, many people arranged jobs for their relatives in a plant that developed a majority Māori workforce. Hence strong kin networks and even an extended "Southdown family" developed at the plant, a family that included partners and children outside the factory. ${ }^{78}$ "It was like a second home", said one Māori worker. ${ }^{79}$ However, others were more cautious about the extent of meatworkers' solidarity. Steve Ruru said at Whakatū friendships developed between the majority of workers rather than all workers. ${ }^{80}$

Workplace-whānau were created and maintained on an everyday basis on the killing floor through numerous means: socializing and mutual support inside and outside the workplace; industrial struggle; initiation rituals; humour and practical jokes; and using sanctions against those who transgressed informal rules. ${ }^{81}$ Meatworkers remembered that, to a degree, they went to work for this camaraderie, rather than for the tedious work itself. Hape Huata explained at Whakatū "it was a way of life. We all looked forward to going to work because it was whanau". ${ }^{82}$ Tatane Te Kahu remarked it was a soul-destroying job, so people frequently attempted to make it fun at

76. Anonymous quoted in Keefe-Ormsby, Tihei Mauri Ora, p. 33. Keefe-Ormsby's study was based on interviews with former Māori meatworkers at Whakatū, a plant where about forty per cent of the workforce were Māori. Ibid., p. I.

77. Quoted in Poi E: The Story of our Song, directed by Tearepa Kahi (Auckland, 2016 [documentary film]), 7'II" to 7'Is". The figure of seventy per cent is from Locke, Workers in the Margins, p. 82.

78. Nicholls and Piesse, The Consequences of Closure, pp. I54-156, 176.

79. Anonymous quoted in ibid., p. I 56.

80. Interviewed in The Black Singlet Legacy, 39'38". Bruce Jesson argued a family atmosphere only developed in some departments. Jesson, "The Freezing Works Strike”, Metro, July 1986, p. 74 .

8 I. Meat plants were "focal points of social activity". Social clubs organized picnics and hangi (a gathering at which food is cooked in an earth oven), and meat plants also had their own sports teams and Māori cultural clubs. Nicholls and Piesse, The Consequences of Closure, p. I 55 .

82. Quoted in "What's the Damage", Mana, 4I (200I), p. 42. See also the comments made by Steve Ruru in The Black Singlet Legacy, 39'35" to $39^{\prime} 45^{\prime \prime}$. 
Burnside meatworks. ${ }^{83}$ Water hose fights, throwing fat, blood, excrement, glands, and meat at each other (and supervisors), and singing and dancing were reportedly commonplace across the industry in the 1970s. ${ }^{84}$

Workplace-whānau involved not just Māori, but also other Polynesians, such as Tongan and Samoan migrants, as well as Pākebā (whites). Charles Pomana, who worked at Whakatū, said, "away from our homes, we were like at home. It was a great big melting pot with many different ethnic groups, different sorts of people, perhaps predominantly Māori, but there was a camaraderie there". ${ }^{85}$ Workplace-whänau also generally represented a working-class oppositional solidarity to employers. In many plants, a strict "us and them" adversarial separation existed between workers and management (including supervisors), who were nicknamed "red hats". Yet, in some factories management attempted to include themselves in the family, or to foster divisions between workers, by, for example, employers organizing a whare (house) system based on occupational departments at Southdown. ${ }^{86}$

Workplace-whānau were not just a product of agency and culture. They were also shaped, to some extent, by the nature of the labour process namely the interdependent nature of working in the meat industry, which required cooperation between workers both within and between occupational departments. Frank McNulty asserted solidarity "easily developed" between meatworkers as they worked in groups, carried out tasks collectively, and assembly-line work made their "identity of interests the same" ${ }^{87}$ Workplace-whänan were also moulded, to some degree, by the Keynesian class compromise. As work was largely plentiful until about the late I970s, and became largely stable, particularly through union-controlled re-hiring of workers on the basis of seniority every new killing season, it enabled workers - including Māori - to gradually build up lasting flaxroots connections over time. For example, Syd Taukamo, the Vice-President of the Whakatū sub-branch of the MWU, said:

If anything happened to a workmate they felt for that person as if it were his brother or his sister. And that's the feeling you get working in an industry for

83. Tatane Te Kahu (also known as Tatane Wesley), interview by Shaun Ryan, 2 I April I999, ATL, Trade union oral history project, tape recording, tape 3 side A, 21'20" to $23^{\prime} 40$ ", OHint $-0478 / 03$.

84. Boraman, "Wildcat Homers"; Harry Cooper, Whakatu Works: Io Year Reunion 1996 (Clive, 1996), p. 5; Rata, Longburn Freezing Works, p. 36; and Webb, “'Your Livelihood is on the Line"”.

85. Quoted in The Black Singlet Legacy, 24'5" to 24 '24".

86. Nicholls and Piesse, The Consequences of Closure, p. I 54; and Socialist Action, 9 February 1979 .

87. Frank McNulty, “The Place of Industrial Relations in Works' Efficiency - papers to be presented to the eleventh Meat Industry Research Conference, Hamilton, July 8-10 1969”, p. 97, ATL, Roth papers, 94-106-39/06. McNulty was then the Secretary of the MWU. 
so long [...] OK the money was there, sure, but that aroha [love or empathy] was the biggest thing that I remember most. ${ }^{88}$

Furthermore, analogous workplace cultures to workplace-whānan do exist, and have existed, in several other industries with similarly collective, dangerous, and interdependent work in Aotearoa New Zealand, including Pākehā-dominated (i.e. non-Māori) industries. Indeed, Ken Findlay, the Secretary of the West Coast branch of the MWU and of the Ngāti Kahungunu and Ngāpuhi iwi (tribes), said meatworkers' culture resembled the masculine "crew culture" that existed amongst miners, seafarers, port workers, construction riggers, and others. ${ }^{89}$ Additionally, similar filial atmospheres have existed in a multitude of worksites and industries globally in far different cultural contexts..$^{90}$ In contrast to the multi-ethnic nature of workplace-whānan, white miners in South Africa utilized their crew culture as a basis to "implement racially and ethnically exclusionary labour practices", thus supporting the transnational praxis of "White Labourism". ${ }^{11}$

These examples indicate that certain material and historical conditions often foster, or are necessary but not sufficient conditions for, sustained camaraderie. Nevertheless, the specific forms this solidarity - racist or anti-racist - takes varies according to different conditions and cultures. This is evident in workplacewhānau. Māori created them to self-manage, to a degree, work rhythms according to their cultural norms, thus making workplaces less culturally alienating and racist, and to gain limited autonomy from the pressures of work. In the process, they often became foundation stones for dissent.

Although workplace-whānan could impressively transcend stratifications between workers, multiple tensions persisted. These included divisions within Māori - such as tribal and hapu (sub-tribal) divisions - between different ethnicities, between workers of different ages and seniority levels, between workers of different sexualities, social status, and sometimes political beliefs, and especially between different occupational groups of meatworkers and genders. For example, conflict sometimes erupted between butchers and other occupational groups..$^{22}$ Butchers, who frequently included many Māori males, were

88. Quoted in The Black Singlet Legacy, 25'I" to 25 '22".

89. Findlay, interview, $\mathrm{I}: 38^{\prime} 00^{\prime \prime}$ to $\mathrm{I}: 38^{\prime} 40^{\circ}$ ". Crew culture is a term coined by James Belich in his Paradise Reforged: A History of the New Zealanders from the I880s to the Year 2000 (Honolulu, HI, 200I), pp. I 8-I9. Meatworkers' workplace cultures resembled crew culture in generally valuing "strength, toughness and manual skills" (ibid., p. 43I) and drinking, but differed in that they were not based on largely white, transient groups of "wandering men".

90. As Paul Willis has documented in the construction industry in the UK in his Learning to Labour: How Working-Class Kids Get Working-Class Jobs (Aldershot, 2000); and Rick Fantasia in the US in his Cultures of Solidarity (Berkeley, CA, I988).

91. Jonathan Hyslop, “The Imperial Working Class Makes Itself 'White': White Labourism in Britain, Australia, and South Africa Before the First World War", Journal of Historical Sociology, I 2 (1999), pp. 398-42 I.

92. See for instance Howells and Alexander, "A Strike in the Meat Freezing Industry". 
often the best-paid and most militant workers due to their strategic position near the start of the dis-assembly line. The extent of these separations varied temporally and spatially, within and across meatworks.

Further research is needed to discern if tribal and sub-tribal based divisions between Māori were overcome in meatworks. The limited evidence available suggests they generally were. In many plants, Māori from different $i w i$ (tribes) and hap $\bar{u}$ (sub-tribes) worked together, particularly in the urban ones. Yet, most reports suggest considerable solidarity existed between different $i w i$ in these metropolitan plants, including Petone and Ocean Beach. At the Pātea meatworks several iwi - all with long-standing historical enmities - worked side by side, hence the local union branch attempted to circumvent potential conflicts by traditionally electing a white union president. ${ }^{93} \mathrm{At}$ other provincial plants, such as Tōmoana, Māori were seemingly primarily drawn from the local iwi.

Webb contends that two competing accounts exist from Māori themselves about Māori/non-Māori $(P \bar{a} k e h \bar{a})$ relations in meatworks. ${ }^{94}$ Some Māori thought non-Māori adopted Māori customs, rather than vice-versa. For example, Te Huia recalled that " $P \bar{a} k e h \bar{a}$ adopted their [Māori] ways, adopted their language, adopted their humour and everyone got on and they were all kind of the same". ${ }^{95}$ This adoption was sometimes reinforced by intermarriage between Māori and Pākehā meatworkers.

Yet, other Māori stressed class and occupational bonds transcended cultural differences. O'Keefe asserted ethnic differences "didn't exist" in meatworks: "you were Pākehā, I'm Māori [...] You were my workmate [...] You didn't see colour. You just saw your mate". When racism flared in meatworks, George Rarere claimed that "the union wouldn't tolerate that sort of thing [...] Or if the union didn't control it [...] families would control it and deal to it". ${ }^{6}$ For example, a wildcat occurred at the Whakatū meatworks after a foreman called a Māori worker a "black bastard". ${ }^{97}$ When James Robb, a former Tōmoana meatworker, sought jobs elsewhere in the early I980s, he found racism far more prevalent in smaller workplaces without a strong Māori presence - in, for example, glue and fish processing factories. $^{98}$ However, in general, while meatworkers' unions endorsed anti-racist policies, ostensibly they did not place prime importance on opposing racism. For example, in contrast to the United Packinghouse Workers of

93. Findlay, interview, 4:07'50".

94. Webb, "Your Livelihood is on the Line", pp. 73-75.

95. Quoted in ibid. p. 73.

96. O'Keefe and Rarere quoted in ibid. p. 73.

97. Ibid., p. 100.

98. Robb, interview, I:57'35" to I: $57^{\prime} 45^{\prime \prime}$. 
America, they did not organize anti-discrimination campaigns. ${ }^{99}$ This subject of the extent and shape of racism on the shop floor, and within unions, and how it was resisted or incorporated (or both) into the meat industry, is beyond this article's scope, and requires further research.

Meatworkers' dissent and workplace-whānan were often based on masculinity. John Leckie claims typical male meatworkers were perceived as being physically and mentally tough, and viewed industrial relations "as a constant tug-of-war" between themselves and bosses, a tug-of-war that required all the attributes of male strength. ${ }^{100}$ "Māori working-class masculinity", as Webb calls it, had a large impact on many plants. ${ }^{\text {IOI }}$ The seemingly predominant "hard men" masculine culture in the meat industry - for both Māori and non-Māori - revolved around valuing rugged physicality, manual skills, and "mateship" or mutual comradeship and loyalty. ${ }^{102}$ Such solidarity was not only developed through working together, but also by socializing and playing sport together outside work. For Henry Williams, a Māori meatworker at Ocean Beach, entertainment after work with fellow meatworkers came through rugby, alcohol, and gambling, "probably in that order". ${ }^{103}$ Subsequently, female partners and children could sometimes be neglected. ${ }^{104}$

Such masculinity was enabled, to some extent, by the strong gendered division of labour that existed in meat plants. Women, including Māori women, were confined to the dirtiest, smelliest, and lowest paid occupations, such as in the manure, offal, and gut/casings departments. Yet, as the influence of the women's liberation movement grew, and the impacts of the recession began to bite, women increasingly began to seek jobs in the industry during the I970s, only to find that employers, unions, and male workers alike often opposed their entry. Initially, some Māori male meatworkers saw women entering the meatworks "as a breach of camaraderie". ${ }^{105}$ Some were especially opposed to women gaining the higher paid, more skilled jobs, such as butchering. In 1978, the Ocean Beach union branch voted to ban women from becoming butchers. Taurima believed that the butchers'

99. See Roger Horowitz, "Negro and White Unite and Fight!": A Social History of Industrial Unionism in Meatpacking, 1930-1990 (Urbana, IL [etc.], I997).

ı००. John Leckie, "Women in Industrial Action: Some Female Profiles in a Redundancy Strike in Vestey's New Zealand Meat Works, I988”, Labour History, 6I (I991), pp. 90-9I.

гог. Webb, "Your Livelihood is on the Line", p. iा.

102. Findlay, interview, I:38'05", г:50'17" to 1:50'55", and Brendan Hokowhitu, "Tackling Māori Masculinity: A Colonial Genealogy of Savagery and Sport", The Contemporary Pacific, I6 (2004), pp. 259-284.

103. Quoted in The Black Singlet Legacy, 17'45" to I7's I".

104. For instance, see the interview with Dalvanius Prime, a former meatworker and prominent member of the Pātea Māori Club, in the Daily Nerws, I 8 August 200 I.

I05. Keefe-Ormsby, Tihei Mauri Ora, p. 30. For a wider discussion, see Locke, Workers in the Margins, pp. 63-66. 
working environment was "in blood and guts", so "it is undignified for women to work on the chain" and further alleged women could not perform the physically demanding job. ${ }^{106}$ At Kaiti, Paenga said "I was opposed to two pays coming into the one house while there were other people who required the money more." ${ }^{107}$

Despite this sexism, women became employed as butchers for the first time across the industry during 1978, and the percentage of women working in the industry increased to eight per cent by 1979 (Figure 3). ${ }^{108}$ It appears that many women eventually became enmeshed within the bonds of shop floor solidarity; however, evidence suggests they often did so by "becoming one of the boys". ${ }^{109}$

\section{THE MID-I970S TO THE MID-I 980 S: RESTRUCTURING, RESISTANCE, AND RETREAT}

This later phase was shaped by the onset of a protracted recession in 1973, as the oil shock and the UK joining the European Economic Community - and the consequent loss of the guaranteed British market for Aotearoa New Zealand pastoral exports (including meat) - had dramatic and lasting effects. Belich has over-optimistically argued that Māori experienced a "golden age" in terms of increased income and access to jobs between the late I930s and the early i970s. When this economic upswing crashed in the mid-1970s, it created a "fertile ground" for activism, including a major surge in Māori protest, especially against ongoing land alienation (highlighted by the pivotal I975 national land march). ${ }^{\text {IO }}$ Yet, Belich overlooks how struggle over both Māori and workplace issues peaked at roughly the same time, and sometimes both movements loosely influenced each other. In workplaces, Māori workers' bargaining and associational power (through developing strong unions and workplace-whänau) had risen under conditions of full employment and the long boom. This generated rising expectations and a

106. Quoted in the New Zealand Herald, 20 September 1980, ATL, Roth papers, 94-106-39I 2.

107. Quoted in Gundry, Making a Killing, p. I 57.

108. Eileen Morgan, Meat Works are for Women Too (Auckland, 1984), p. 2; and New Zealand Meat Worker, December 1979, p. 25.

I09. Keefe-Ormsby, Tihei Mauri Ora; and Webb, "Your Livelihood is on the Line”, p. 77. I Io. Belich, Paradise Reforged, pp. 473-475. Further, Māori protest also included opposing racism, assimilationist government policies, and the suppression of Māori culture and language. For overviews see Aroha Harris, Hīkoi: Forty Years of Māori Protest (Wellington, 2004); and Evan Poata-Smith, "He Pokeke Uenuku i Tu Ai: The Evolution of Contemporary Māori Protest", in Paul Spoonley et al. (eds), Nga Patai: Racism and Ethnic Relations in Aotearoal New Zealand (Palmerston North, I996), pp. 97-1 I6. 


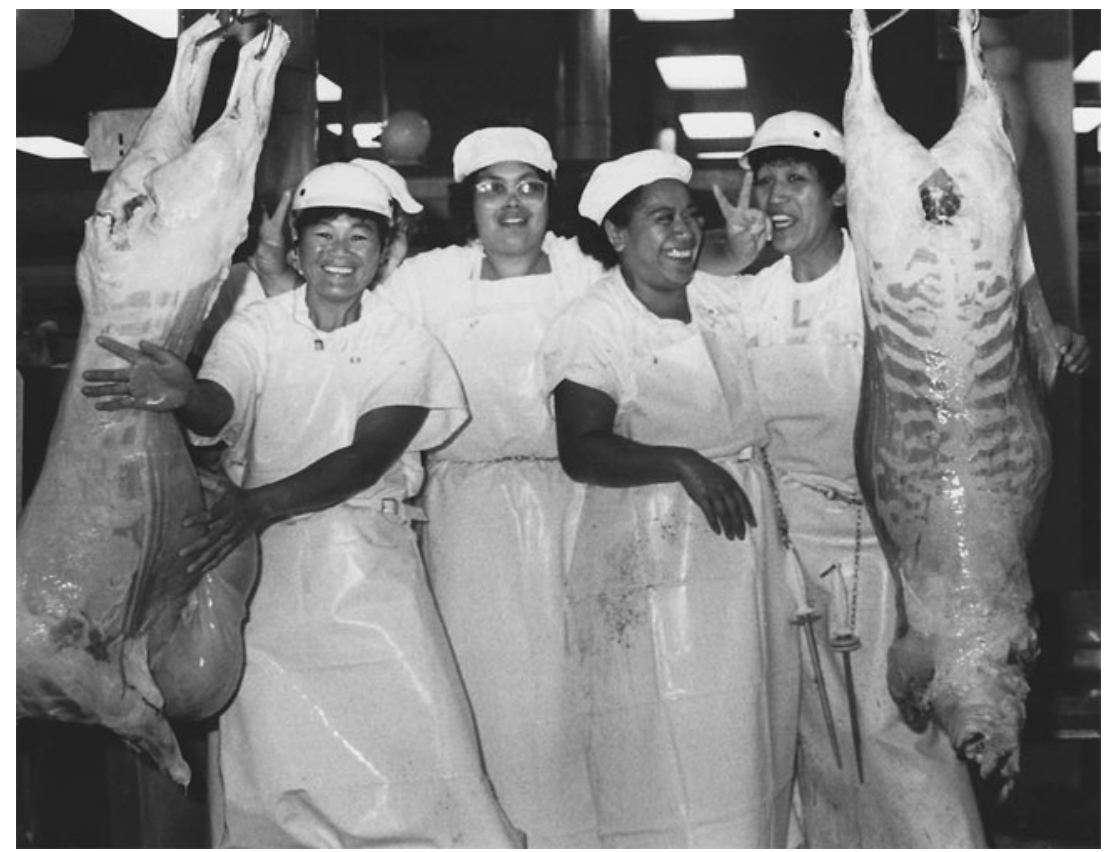

Figure 3. From left to right: Mere Chong, Mahina Barlow, Helen Barlow, and Katy O'Keefe in the Tōmoana meatworks, n.d., c.I980s, available at: https://numawaruwire.wordpress.com/tag/ tomoana/\#jp-carousel-638; last accessed 22 January 2019.

greater capacity to confront capital and the state through stoppages when these conditions halted.

From about the mid-r970s, strike action generally became more widespread in response to declining real wages, high inflation, increasing government intervention in bargaining to limit wage increases, and especially the beginnings of the downsizing of manufacturing that marked the end of full employment. ${ }^{\text {II }}$ While wildcats and local bargaining strikes continued indeed, a major national confrontation occurred at Ocean Beach in 1978 when the government charged 192 Ocean Beach meatworkers for striking illegally, but backed down under pressure from the MWU - they generally became less successful and prominent. Instead stoppages during this phase typically became more defensive, lengthy, and bitter.

Māori meatworkers played a more prominent role in disputes during this phase than the earlier one. Indeed, some explicit links between Māori culture and workplace activity materialized. At Petone, Ben Matthews had organized quickly. Jonathan Boston, Incomes Policy in New Zealand 1968-84 (Wellington, I984), p. I8. 
"the stroppier Maori slaughtermen [butchers] into a fighting force [...] Maori butchers became the spearhead of the union". ${ }^{12}$ Matthews unequivocally linked land alienation with strikes by Māori, deeming them a direct form of compensation from the capitalist class:

Maoris who once had NZ as their agricultural paddock have been forced off by the capitalists and are now screwing that same establishment for the products of that stolen land. I commend that line of reasoning for all Maoris and Maori freezing workers [meatworkers]. ${ }^{\mathrm{II} 3}$

Keith Locke, who worked at Petone and later became a politician, also noted the concurrent influence of Māori culture on the union: plant-wide union "meetings became very open, democratic affairs, taking on almost a marae character. They continued until everyone had their say [...] I remember one going all day". ${ }^{I 4}$ Marae are communal meeting complexes of Māori sub-tribes $($ hap $\bar{u})$.

Pātea was another majority Māori and formerly conservative plant like Petone that developed an intense level of everyday and overt industrial conflict during the late i 970 s and early i 980 s. An extraordinary level of absenteeism arose because hundreds of Māori frequently needed to attend tangihanga (funeral ceremonies) that often lasted three or more days at local marae. ${ }^{I I S}$ According to Tony Raimona, Secretary of the Pātea subbranch of the MWU, a factor in causing these conflicts was that Pātea Māori felt they were in a "bonded relationship" with Vesteys - the British corporation that owned the plant - presumably because of the scarcity of other local employment opportunities in a virtual company town. Hostility to the company intensified after it was discovered in the local library that Vesteys treated Australian Aboriginal workers in an allegedly brutal fashion. ${ }^{116}$

Industrial action explicitly in support of Māori causes was only rarely undertaken, such as when Petone meatworkers struck for a day in 1978 to protest the government's eviction of a seminal Māori land occupation at Takaparawhà (Bastion Point) in Auckland during 1978. ${ }^{\text {II7 }}$ In contrast to

I I 2. Locke, "A History of Struggle", p. 5.

I I 3. Ben Matthews in Te Matakite o Pōneke's newsletter Tihei Mauri Ora, October 1978, cited in Socialist Action, is December 1978.

I I 4. Locke, "A History of Struggle", p. 5.

I I . Findlay, interview, 4:08'52" to 4:II'I5"; and Ray Potroz, cited in Angove, "Worker Indiscipline”, p. 28. However, while management at some plants like Pātea did not seemingly accommodate Māori customs, others did, such as at Whakatū. See The Black Singlet Legacy, $23^{\prime} 48^{\prime \prime}$ to 24 '०3".

I 16. Nancy Angove, "Worker Indiscipline in the Freezing Industry: A Patea Case Study" (BA thesis, Massey University, I988), pp. 3, I 3. In part to oppose this "brutal" treatment, but also to demand the return of their land, Gurindji farm labourers held a significant strike against Vesteys from I 966 to 1975. See Riddett, "The Strike that Became a Land Rights Movement".

I 17. Socialist Action, 2 June 1978. 
the United Packinghouse Workers of America in the US, both major meatworkers' unions were not adherents of "social unionism", and thus did not seek coalitions with community-based social movements, such as the Māori protest movement. ${ }^{\mathrm{I} 18}$

Most strikes involving Māori ostensibly centred on economic issues. For example, the aforementioned strikes at Pàtea were part of a wider series of struggles from the late I 970 s to the early I990s against capital's comprehensive restructuring of the meat industry. Older slaughterhouses, such as Petone, were threatened from the late I970s onwards with closure unless considerable layoffs and pay cuts, and transformed working conditions, were accepted. Further, the government's deregulation of the industry in I98 I helped to further fuel the "new mood of belligerence and arrogance" among employers (Figure 4). ${ }^{\text {II }}$ Subsequently, disputes generally escalated, as a pattern of localized strikes against downsizing emerged. For instance, Petone meatworkers were locked out for several months during 1979 and I98 I after they rejected severe pay cuts of twenty per cent and major job losses in order to circumvent shutting the plant down (Figure 5). ${ }^{\mathrm{I} 20}$ Their action, while unable to avert restructuring and ultimately the closure of the slaughterhouse, significantly reduced the extent of proposed wage and job cuts.

While most stoppages against restructuring were localized, several significant national strikes in which Māori were also prominent were undertaken, such as in 1980 when the FWU, unsupported by the MWU, took national strike action that helped to re-open the closed Southdown plant. However, this gesture was temporary; Southdown then closed for good in $198 \mathrm{I}$. The most significant nationwide attempt to halt restructuring - the I 986 national strike, when the MWU struck for six weeks and the FWU held out for eight, which represented the largest dispute nationally in terms of working days not worked since $195 \mathrm{I}$ - was similarly unable to stem the neo-liberal tide. ${ }^{\mathrm{III}}$

Nevertheless, workplace-whänan were crucial for sustaining the lengthy stoppages that occurred against restructuring, and in enabling the considerable creative rank-and-file organization that developed in many of these disputes. For instance, Petone meatworkers in the late I970s and early I 980 s employed tactics such as sit-ins of company headquarters, pickets of Gear retail butcher shops, and industrial "guerrilla warfare" tactics. In both

I 18. Horowitz, "Negro and White Unite and Fight!"

I 19. Trevor Kelly, District Secretary of the FWU, in Your Livelihood is on the Line: The Future of the Meat Industry (n.p., I981), p. 3.

I 20. Warwick Johnston, The Gear: A History of the Gear Meat Preserving E Freezing Company (Wellington, 20I 2), pp. 94-95; and Socialist Action, 2 November 1979, 30 November 1979 and 6 March I98I.

I 2. New Zealand Meat Industry Association (Inc.) Annual Report 1986-87 (Wellington, n.d.), p. I4. See also Locke, Workers in the Margins, pp. I57-1 58. 


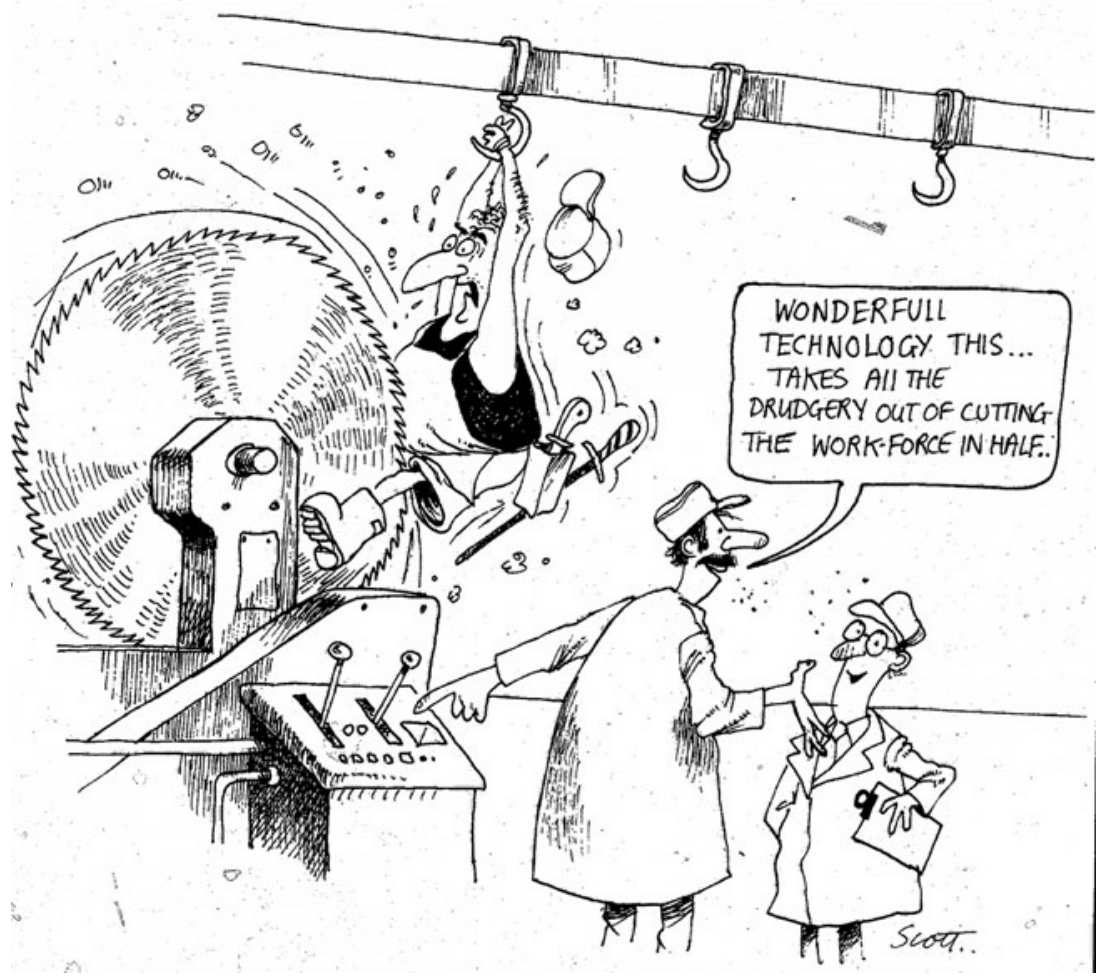

Figure 4. Cartoon by Tom Scott in Roger Middlemass, 4 for 5: The Workers' Response to Mechanisation and Automation in the Freezing Industry (Wellington, I98I), p. I.

lockouts at Petone - as with many other major strikes during the same period - various elected rank-and-file committees were formed to support strikes. Relief centres, often run by female partners of meatworkers, were established during lockouts. ${ }^{\mathrm{I2}}$

Workplace-whānau often went beyond the workplace and into the home and community. ${ }^{{ }^{2} 3}$ Solidarity inside workplaces was supplemented by solidarity outside it. The widespread, but not universal, support meatworkers received from local communities generally reflected the strong neighbourhood bonds that Māori often created over time in nearby suburbs or towns that relied on meatworks for employment. For example, in Petone then a predominantly Māori industrial suburb of Wellington - a close-knit

I 2. New Zealand Meat Worker, Dec. 1980; and Socialist Action, 2 November 1979 and 6 March I98I.

I 23. Nicholls and Piesse, The Consequences of Closure, p. I54; and Williams, Panguru and the City, p. 190. 


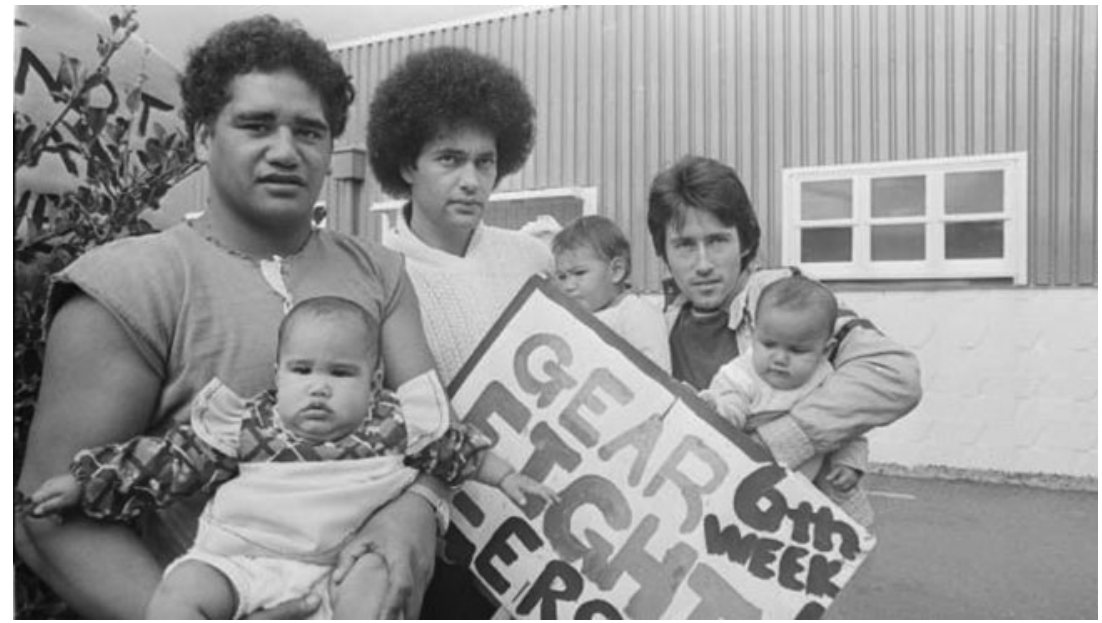

Figure 5. Locked out Petone meatworkers with their children during the sixth week of the I98 I lockout. Left to right: Thomas Meihana with Selina, Glen Rainford with Hemi, and Malcolm McAllister with Kimiora. Evening Post, 6 April 198I, EP/I98I/I406/30A-F, Alexander Turnbull Library.

community developed. One author romantically described Petone as "one big family" with everyone caring for each other. ${ }^{124}$ Many locals readily supported Petone meatworkers because they had either worked in the Petone slaughterhouse themselves, or knew relatives or friends working there, or had worked alongside Petone meatworkers during their off-season employment. ${ }^{\mathrm{I} 25}$

As in the earlier phase, strike activity still varied widely between companies, regions, plants, and occupational departments. While the general trend was that of a heightened level of overt antagonism when compared with the late I960s and early I970s, several slaughterhouses with large Māori workforces, such as Shortland, shifted from being conflict-prone to conflict-averse after adopting strategies of cooperation with management in response to management overtures in the late 1970 s before the onset of restructuring. ${ }^{\mathrm{I} 26}$ Likewise, in response to the tumultuous 1978 conflict at Ocean Beach, the company and union developed local conciliation policies, and so that meatworks experienced a largely stoppage-free 1979-1980 season.

I24. Johnston, The Gear, p. 98.

I 25. Socialist Action, 16 November 1979 and 6 March 198 I.

I 26. New Zealand Herald, 9 October 1974 and 23 January 1979, ATL, Roth papers, 94-106-39/ 07 and 94-106-39/1 2 respectively. The Socialist Action League argued this cooperation came at the expense of working conditions, including sped-up production, in order to make the plant more profitable. Socialist Action, 8 August 1986. 
Yet, major disputes re-emerged after a new company acquired the plant in I $98 \mathrm{I}$ and began to cut jobs and slash pay by thirty per cent. ${ }^{\mathrm{I}}{ }^{17}$ Some conservative union officials, such as Paenga, argued that greater collaboration with employers, rather than struggle against them, was necessary in response to retrenchment, and thus largely avoided undertaking strikes. However, this strategy also failed to halt job losses and wage cuts. Further, meatworkers remained internally divided over supporting strikes. As Ngahiwi Tomoana noted at Whakatu "if the decision was passed by vote to go on strike for a day [...] heads would shake sadly, while others would whoop and rush for the door". ${ }^{28}$

As disputes became more prolonged during this phase, many Māori found they simply could not afford to stay out on strike. The lack of income frequently created tensions within homes. Male meatworkers frequently did not inform female partners about why strikes were occurring. Many meatworkers' partners also resented disputes due to the suffering they caused, especially the inability to feed children. ${ }^{\text {I29 }}$ On a few occasions, they protested against meatworkers' strikes, including, for example, fifty women at Pātea in $1979 .{ }^{130}$ In response, the West Coast branch of the MWU included meatworkers' partners - at Pātea, Petone, and elsewhere - in union meetings, and this soon became an accepted practice elsewhere, inside and outside the industry. Additionally, meatworkers' partners became increasingly involved in strike support.

As increasing numbers of Māori women became employed as meatworkers, some professed an initial scepticism of strikes because many had previously worked in generally strike averse industries. ${ }^{{ }^{13} \mathrm{I}}$ Yet, they played a leading role in stoppages of the late 1970 s and $1980{ }^{132}{ }^{132}$ For example, at a new highly automated model plant built in I98 I at Oringi, management hired a higher proportion of inexperienced and female meatworkers (about twenty per cent were women and many were Māori) in an endeavour to weed out potential "trouble-makers" and lessen militancy. ${ }^{\mathrm{I} 3}$ Yet, this strategy backfired as female Oringi workers were at the forefront of defeating management's attempt to establish a company union, and then led a series of disputes during 19821983, including a six-week lockout in 1983 . Heather Kopua, the vice president

I 27. New Zealand Herald, 2 February 1984, ATL, Roth papers, 94-106-4I/II; Paske, "The Tide Turns"; and Socialist Action, 24 February 1984.

I 28. Ngahiwi Tomoana, "Unions Held Everything Together Through Thick and Thin", Hawkes Bay Today, i 8 October 2016.

I29. Findlay, interview, I:57'54" to I:58' 17".

I30. Auckland Star, 7 June 1979, ATL, Roth papers, 94-106-39/1 2.

I3 I. See, for example, various interviews in Socialist Action: Orien Karaitiana (I May 198 I); Heather Kopua (I4 June 1985); and Shirley Tareha (I 8 May 1984).

I32. See Leckie, "Women in Industrial Action".

I33. Graeme Lowe, director of the firm that owned Oringi, quoted in Calder and Tyson, Meat Acts, p. 193 and Morgan, Meat Works are for Women too, pp. 7, 10. 
of Oringi sub-branch of the MWU noted, "women have played a vital part in this union" even if the majority still perform the "lesser jobs". ${ }^{\mathrm{I} 4}$

After this wave of disputes, management generally preferred to hire middle-aged married men because they perceived them to be more placid than women. Liz Ngawaka, an Oringi worker, asserted "they think these men are less likely to go on strike or be militant in the union, because they've got families and wives to support". Yet, they also employed men for "chauvinistic reasons, like women get pregnant and have to leave". ${ }^{135}$

Yet, between I98 I - when the meat industry was deregulated - and the late I990s, forty-three new plants were opened and twenty-nine were closed. Employers closed older, "inefficient" larger plants, like Petone in I98 I and Pātea in 1982, and opened smaller, more automated plants, often located in traditionally non-militant rural locations, such as Oringi. ${ }^{136}$ Of the 800 who lost their jobs at Petone, 600 were estimated to be Māori. ${ }^{137}$ Closures became more widespread after generous government subsidies for farming ceased in the mid-1980s. Whakatū closed in 1986, Longburn ceased operating in 1989 after a three-year lockout, and Ocean Beach shut down in 1991. ${ }^{1{ }^{3}}$ Strike activity was frequently blamed for closures.

As the workforce was almost halved in size from the r 970 s to the I990s, new working conditions were imposed - brutal work speeds, longer work hours (including shift work), and stricter management control over the work process. Consequently, the strong union and workplace bonds (including workplace-whanau) that formerly existed gradually frayed over time and by the I 990 s strikes in the industry waned markedly. ${ }^{139}$ One company history asserted "the war zone that was the freezing industry has been comparatively quiet" since the 1980 s. $^{140}$ De-industrialization had traumatic long-term economic, social, and cultural impacts. Māori often fell back on strong community and cultural bonds to help overcome tough times. For example, the Pātea Māori Club, largely composed of former Pātea meatworkers, scored a number one hit sung in Māori in 1984. The song raised money for unemployed ex-meatworkers after the Pātea meatworks closed. ${ }^{141}$

I34. Quoted in Socialist Action, I4 June 1985.

I35. Quoted in Socialist Action, 23 March 1984.

I36. Boraman, "Wildcat Homers", p. 479.

I37. Socialist Action, 29 November 198I.

I38. Locke, Workers in the Margins, pp. I60-16I.

I39. Boraman, "Wildcat Homers", p. 479.

I40. John McCrystal, A Long Season: The Centennial History of AFFCO New Zealand (Wellington, 2004), p. I 23.

I4I. The song was called "Poi E". In 1982, forty-eight out of fifty club members were either meatworkers or in families dependent on the meatworks for a living. Melser et al., Patea After the Freezing Works, p. 39. 


\section{CONCLUSIONS}

Far from being passive, marginalized victims of capital, colonialism, and racism, Māori meatworkers attempted to mitigate their oppression and exploitation through adapting various forms of informal and formal workplace struggle. They were frequently at the forefront of stoppage activity during the I970s and I980s. As Willie Jackson, the President of the Auckland Abattoir branch of the FWU and later a prominent Māori politician, asserted "Maori workers are on the front lines of the strikes. We're the most staunch fighters." ${ }^{42}$

The meat industry provides an example of the continual ebb and flow of class composition and decomposition within broad "cycles of struggle" within capitalism, and how indigenous workers played a vital role in that cycle. To summarize complex and contested historical events: Māori became increasingly employed by meat processing companies during the long boom, working to process animals ironically from farms situated on their alienated lands. Despite the meat processing workforce being seasonal and multiethnic, Māori helped to gradually assemble powerful family-like, yet largely masculine-based, bonds within unions and on the shop floor in many plants. They helped construct what several Māori contended was a "home away from home" in the alleged "one big family" atmosphere of some slaughterhouses. These tight-knit relationships not only made gruelling working conditions more culturally bearable, but also became a basis for dissent, especially during the recession that followed the long boom. Workplacewhānau, as examples of informal work groups with an indigenous twist, became what Jeremy Brecher - in his classic study of US strikes - calls the invisible cell-units of labour unrest, although such workplace-whānau were frequently indistinguishable from the strong union bonds that were also present in the industry, rather than being autonomous from unions. ${ }^{\text {I } 3}$

Then, from the late I970s, capital's restructuring of the meat industry on a more mechanized basis induced management to decompose these informal and formal associational bonds, and introduce a leaner, faster production process as well as a smaller - and more casualized, disciplined, and lowerpaid - workforce. Despite sometimes intense resistance to restructuring in the I980s, by the i990s thousands of Māori meatworkers had been made redundant. Nevis Tomoana, an ex-meatworker at Whakatū, aptly summarized this historical cycle:

previously we were taken from our land and to the meat works as a source of cheap labour. Now they say our labour is too expensive. Now the wheel has come the full circle and we've been thrown out of work. ${ }^{\text {I4 }}$

I42. Quoted in Socialist Action, 28 March 1986.

I43. Jeremy Brecher, Strike! (San Francisco, CA, I972), pp. 233-237.

I44. Quoted in Socialist Action, 2 I November 1986. 
Consequently, for those who remained employed, workplace-whannan became far less prominent, and strike activity precipitously declined across the meat industry in the r 990 .

At the same time, such a broad-based interpretation can firstly overemphasize the resistance and agency of Māori, and thus neglect the deep political, economic, and cultural marginalization of the vast majority of Māori within settler colonialist structures. Secondly, it can neglect the multiple fissures that existed between workers. To examine the first point, although Māori meatworkers were strategically located in a globally important meat industry, they were highly vulnerable to the comprehensive industry restructuring that occurred in the I980s. Their agency (in terms of their largely localized traditions of solidarity and resistance) was not enough in itself to avert this structural reorganization. Further, while workplacewhānau were seemingly a distinct product of Māori autonomy, they somewhat resembled masculine workplace cultures formed in many other blue-collar industries nationally and globally. Indeed, the forms workplace-whanan took in the meat industry were as much a product of Māori culture as they were of union culture, class antagonism, and material conditions, including the work process and the Keynesian class compromise.

The extent of Māori meatworkers' recalcitrance and solidarity varied significantly spatially and temporally in the long I 970 s across plants, companies, and unions. While a general correlation between meatworks with significant Māori workforces and a high incidence of stoppages existed, several meatworks with a disproportionate number of Māori employees had relatively low levels of strike activity. Some meatworks with significant Māori workforces fluctuated from low levels of contestation to high levels in the I970s and I980s, such as Petone, while a few experienced the opposite trend, such as Shortland, and yet others zigzagged back and forth, such as Ocean Beach. Overall, tracing the specific Māori influence on work stoppages is difficult given the multi-ethnic cooperation that existed in many plants; indeed, stoppages by their very nature attempt to unite different ethnicities for a common aspiration. Jackson Smith, from the Ngāti Rakaipaaka hap $\bar{u}$ of the Ngāti Kahungunu iwi, and a prominent unionist in the I970s and I980s in the Wellington Drivers' Union, pertinently concluded that Māori workers were not essentially rebellious or conservative:

In unions with a high Māori content their work stoppage record is probably greater than those organizations with a lower Māori content. I'm talking about drivers $[\ldots]$ timber workers, watersiders, labourers [...] [and] freezing workers [meatworkers] ... [Yet,] I can't point to a distinction that Māori had something special about stopping work, as opposed to Pākehā or anybody else. Because we had some outstanding Pākehā members [...] who themselves would be leaders in 
the stoppage. So, there was no real difference in the responses, whether Māori or $P \bar{a} k e b \bar{a}$, and I'm [only] speaking for our union. ${ }^{145}$

To some extent, variations in strike levels across plants were caused by the shifting attitudes and practices of management in response to economic crisis, and by the similarly complex conflictual or cooperative strategies of local branch union officialdom. As such resistance - or the lack of it - was often seemingly shaped from above, despite evidence that disputes frequently arose from rank-and-file grievances.

Secondly, while Māori and Pākehā meatworkers were generally and sometimes impressively unified on the killing floor, such solidarity was not omnipresent or without multiple tensions, including between Māori and non-Māori, between Māori (such as between Māori union officials and the rank-and-file), between different occupational groups, between different plants and unions, and especially between genders. Solidarity - and resistance - in the meatworks sat squarely within the complex, multifaceted entanglements of indigeneity, ethnicity, colonialism, gender, capital, and class. Importantly, the oppositional solidarity of strikes "can be mobilized to obscure the very dynamics of colonization that set the stage for - and are sometimes reproduced through - solidary relations" ${ }^{146}$ and thus did not generate opposition to racism and colonization. While many Māori meatworkers solidly supported non-Māori meatworkers during stoppages, few Pākehā workers - apart from a few radicals and other sympathizers - reciprocated and proffered enduring support to Māori struggles against racism and colonialism. Indeed, tensions developed between the Māori sovereignty movement and unions nationally after the lack of concrete union opposition to the apartheid South African rugby tour in $198 \mathrm{I}$, which spurned the largest and most combative social movement in Aotearoa New Zealand during the long I970s. By the mid-ı980s, a rupture emerged among Māori unionists between those who thought the exploitation and racism faced by Māori workers could only be effectively opposed through a union movement that united all workers on a class basis, and those who began to either push for unions to be reformed from within to become more supportive of Māori issues and practices, or to form separate Māori unions. This was due to the perceived indifference of unions to colonialism and racism, and to form institutional union structures more aligned with Māori practices and

I45. Jackson Smith, interview by author, digital recording, Porirua, I9 November 2013, $2: 43^{\prime} 4 \mathrm{I}^{\prime \prime}$ to $2: 45^{\prime} 48^{\prime \prime}$. Smith was a meatworker briefly in his youth and was the inaugural convenor of the Federation of Labour's Māori and Pacific Islands Advisory Committee and a member of the pro-USSR Socialist Unity Party, a party that was generally perceived as seeing Māori issues as divisive.

I 46. Rubén Gaztambide-Fernández, "Decolonization and the Pedagogy of Solidarity”, Decolonization: Indigeneity, Education E Society, I (2012), p. 43. 
values. Reforming unions from within became the dominant current, although meatworkers' unions were slow to act. ${ }^{\mathrm{I} 47}$

\section{TRANSLATED ABSTRACTS \\ FRENCH - GERMAN - SPANISH}

Toby Boraman. Indigénéité, dissidence et solidarité: les Maoris et les grèves dans l'industrie de la viande en Aotearoa ou Nouvelle-Zélande avant, pendant et après les années 1970.

Les études sur la résistance d'ouvriers indigènes se sont largement concentrées sur les travailleurs ruraux. Par contraste, cet article examine la dissidence d'ouvriers indigènes dans un cadre industrialisé et largement urbanisé - celui des ouvriers maoris du traitement de viande en Aotearoa ou Nouvelle-Zélande. Je soutiens que loin d'être des victimes passives de la colonisation et du capitalisme, les ouvriers maoris du secteur de la viande ont joué un rôle souvent vital dans le conflit de travail formel et informel généralement important qui a pris place dans l'industrie de la viande depuis la fin des années 1960 jusqu'au milieu des années I980. Toutefois, la dissidence et la solidarité les travailleurs maoris n'étaient pas universelles mais ont plutôt considérablement varié, tant dans l'espace que dans le temps. La dissidence et la solidarité qui se sont manifestées ont souvent été le produit de groupes de travail informels multiethniques qui existaient dans de nombreux abattoirs. Ces whänau, dans lesquels les Maoris ont joué un rôle pivot, ont fonctionné comme de vastes réseaux familiaux sur le plan d'abattage. Les whānan du lieu de travail ont représenté une importante imbrication d'indigénéité et de classe. Mais comme ils reposaient souvent sur des liens masculins, ils ont fréquemment exclu les ouvrières (et notamment les femmes maoris).

Traduction: Christine Plard

Toby Boraman. Indigenität, Dissens und Solidarität: Die Māori und die Streiks in der fleischverarbeitenden Industrie von Aotearoa/Neuseeland wäbrend der langen I 970 er Jabre.

Untersuchungen zum Widerstand indigener Arbeiter fokussieren oft weitgehend auf ländliche Arbeiter. Im Gegensatz dazu untersucht dieser Beitrag den Dissens indigener Arbeiter in einem industrialisierten und weitgehend urbanisierten Setting: dem der in der fleischverarbeitenden Industrie von Aotearoa/Neuseeland beschäftigten Māori. Im Beitrag wird die These vertreten, dass diese Māori weit davon entfernt waren, passive Opfer der Kolonisierung und des Kapitalismus zu sein; sie spielten vielmehr eine oft ausschlaggebende Rolle in den meist umfassenden informellen und formellen Arbeiterunruhen, die von den späten I960er bis zur Mitte der I980er Jahre in der fleischverarbeitenden Industrie $\mathrm{zu}$ verzeichnen waren.

I47. See Locke, Workers in the Margins; "Māori Sovereignty"; and idem, "From Human Rights to Māori Sovereignty". 
Widerstand und Solidarität der in der fleischverarbeitenden Industrie beschäftigten Māori waren jedoch keine einheitliche Konstante, sondern von beträchtlichen Unterschieden geprägt, sowohl von einem Ort zum anderen als auch über die Zeit hinweg. Wo es zu Dissens und Solidarität kam, waren diese häufig Ergebnis der multiethnischen informellen Arbeitsgruppen, die es in vielen Schlachthöfen gab. Diese Arbeitsplatz-whānau, in denen den Māori eine Schlüsselrolle zukam, funktionierten auf dem Schlachthof oft ähnlich wie erweiterte Familiennetzwerke. Die Arbeitsplatzwhānau waren eine bedeutsame Verbindung von Indigenität und Klasse. Da sie jedoch häufig auf Männerbeziehungen beruhten, waren Arbeiterinnen (einschließlich Māori-Frauen) oft von ihnen ausgeschlossen.

Übersetzung: Max Henninger

Toby Boraman. Indigenidad, disenso y solidaridad: los maories y las huelgas en la industria cárnica en Aotearoa (Nueva Zelanda) en la larga década de 1970.

Los estudios que se han realizado sobre la resistencia de los trabajadores indígenas han venido a centrarse de forma fundamental en los trabajadores del mundo rural. De forma distinta, en este artículo vamos a analizar el disenso en un ámbito industrializado y ampliamente urbanizado: el de los trabajadores maoríes de la industria del procesado de la carne en Aotearoa (Nueva Zelanda). Consideramos que lejos de ser víctimas pasivas de la colonización y el capitalismo los trabajadores maoríes de la industria cárnica jugaron a menudo un papel fundamental en la extensión generalizada de la agitación formal e informal que sacudió este sector industrial a finales de la década de 1960 y se prolongó hasta mediados de la década de 1980. Sin embargo, la resistencia y la solidaridad de estos trabajadores no fue universal sino que encontramos una variedad de situaciones significativa, tanto a nivel espacial como temporal. La protesta y la solidaridad que se articularon fueron a menudo resultado de agrupaciones laborales informales multiétnicas que se formaron en un número importante de mataderos. Estos espacios de trabajo (whānau) en los que la población maorí jugó un papel crucial funcionaron en un nivel básico de forma similar a las redes familiares extensas. El espacio de trabajo (whānau) representaba una interconexión significativa en lo referente a la indigenidad y la clase. Aun así, como principalmente se basaban sobre vínculos masculinos, de forma frecuente las mujeres trabajadoras quedaron excluidas, incluidas las propias maoríes.

Traducción: Vicent Sanz Rozalén 